\title{
Comparison of Intravenous Glucose Tolerance Tests and Serum Insulin Levels in Kwashiorkor and Pellagra
}

\author{
J. G. PRINSLOO, E. J. P. DE BRUIN, and H. KRUGER \\ From the National Institute for Nutritional Diseases (South African Medical Research Council), the Department of \\ Paediatrics (Medical Faculty, University of Pretoria), and the Division of Life Sciences, South African Atomic Energy \\ Board, Pretoria, South Africa
}

\begin{abstract}
Prinsloo, J. G., de Bruin, E. J. P., and Kruger, H. (1971). Archives of Disease in Childhood, 46, 795. Comparison of intravenous glucose tolerance tests and serum insulin levels in kwashiorkor and pellagra. Intravenous glucose tolerance tests and serum insulin responses were estimated on admission to hospital as well as after recovery in 16 kwashiorkor and 15 pellagra children.

Only the kwashiorkor group showed impairment of glucose utilization on admission, and the glucose disappearance rate of the two groups differed significantly. After clinical recovery the glucose utilization of the kwashiorkor patients was much improved, and similar to that of the pellagra patients. These findings are different from those of others who reported persistent glucose intolerance after kwashiorkor. The glucose tolerance tests were normal in the pellagra group, both on admission and after recovery. The kwashiorkor group's insulin response was less than that of the pellagra group on admission, and the values of the two groups differed significantly at 5,15 , and 30 minutes after glucose administration. After recovery, the insulin levels of the two groups were similar.

The improvement in glucose utilization which took place on recovery of the kwashiorkor patients, as well as the low incidence of diabetes mellitus in the Bantu, cast doubt on the concept of permanent impairment of pancreatic endocrine function as a result of protein-calorie-malnutrition. It is speculated that glucose intolerance may be related to body potassium deficiency.
\end{abstract}

Pancreatic exocrine function has been reported as depressed during the acute stage of protein-caloriemalnutrition and, though recovery was rapid in most patients, abnormalities persisted in some (Barbezat and Hansen, 1968). Several other investigators indicated that carbohydrate metabolism was disturbed in patients suffering from kwashiorkor (Bowie, 1964; Baig and Edozien, 1965; Hadden, 1967; Hopkins, Ransome-Kuti, and Majaj, 1968; Carter et al., 1968; Wharton, 1970). A tendency to hypoglycaemia is common, yet oral glucose tolerance tests showed a delayed but sustained response, and the disappearance rate of glucose after intravenous administration was retarded. Fasting serum insulin levels have been reported as low (Baig and Edozien, 1965), normal,

Received 3 May 1971. or high (Hadden, 1967), and the serum insulin response after oral or intravenous glucose was diminished in the majority of cases (B. L. Pimstone, 1969, personal communication). Persistent impairment of insulin secretion and glucose tolerance after recovery from kwashiorkor has been reported (Cook, 1968; James and Coore, 1970). In marasmus on the other hand, intravenous glucose tolerance tests were normal (Bowie, 1964). Adult pellagrins showed a diminished glucose tolerance both after oral and intravenous tests (Gillman and Gillman, 1951).

During a previous investigation (Prinsloo et al., 1971) we found that kwashiorkor patients had, on admission, a 'diabetic', and, after recovery, a flat oral glucose tolerance curve, while the response of pellagra patients was normal in both instances. The serum insulin responses of the two groups did 
not differ significantly at either period, though the pellagra patients generally had higher values than the kwashiorkor group. The differences in glucose tolerance of the two groups could have been due to variations in the time of gastric emptying and the rate of absorption.

To exclude these possibilities and also since no other comparisons of glucose utilization between kwashiorkor and pellagra patients seemed to have been done, it was decided to compare the rate of glucose disposal and the serum insulin responses after intravenous tolerance tests in such patients.

\section{Subjects and Methods}

The kwashiorkor group consisted of 16 hospitalized patients (11 male and 5 female) manifesting the typical signs of kwashiorkor, including oedema. Patients who appeared moribund on admission were excluded. The pellagra group comprised 15 children $(9$ male and 6 female) with classical pellagrous skin lesions in the absence of oedema.

Therapeutic regimen. The kwashiorkor patients were given full-strength full-cream milk, additional potassium (300 $\mathrm{mg} 4$ times a day) until disappearance of oedema, tetracycline phosphate syrup $(40 \mathrm{mg} / \mathrm{kg}$ per day divided into 4 doses) for 5 days, ferrous sulphate $300 \mathrm{mg} 3$ times a day, $5.0 \mathrm{ml}$ standard multivitamin syrup daily, and the general ward diet as soon as the patients were willing to eat. The pellagra patients received the ward diet (including milk), nicotinamide tablets $50 \mathrm{mg} 3$ times a day as well as a standard multivitamin tablet 3 times a day. All patients were weighed on admission and daily thereafter. The body weight on admission and after recovery was expressed as a percentage of the expected weight (Boston 50th centile value-Nelson, 1964).

Special investigations. The following tests were done between 2 and 5 days after admission to hospital: $\mathrm{Hb}$ and serum albumin estimations, an intravenous glucose tolerance test after an 8-hour overnight fast $(0.5 \mathrm{~g}$ glucose $/ \mathrm{kg})$-venous blood was collected in the fasting state and at $5,15,30,45$, and 60 minutes after glucose injection for the determination of blood sugar and insulin levels. Insulin and glucose concentrations were determined as previously described (Prinsloo et al., 1971), using the methods of Hales and Randle (1963), and Hoffman (1937). The disappearance rate of glucose after intravenous injection ( $K$ value) was calculated as described by Lundbaek (1962). Total serum proteins were estimated according to the biuret method of Weichselbaum (1946), and albumin was calculated after electrophoresis was carried out with the aid of the microzone cellulose acetate method, using the model R100 Spinco-Beckman microzone cell, and read on the microzone scanning attachment. The tests were repeated between 4 and 5 weeks after admission to hospital (recovery). The values of the kwashiorkor and pellagra groups on admission as well as after recovery were compared for significant differences using the WilcoxonMann-Whitney two-tailed U test (Siegel, 1956) The results of each group were also tested for significant differences from admission to recovery by means of the Wilcoxon matched-pairs-signed-ranks test (Siegel, 1956). In all tests a probability $P<0.05$ was regarded as significant.

\section{Results}

The average and median values for age, weight, percentage expected weight, $\mathrm{Hb}$, serum albumin, blood glucose, serum insulin, and glucose disappearance rate ( $K$ value) in kwashiorkor and pellagra groups can be seen from the Table. The median values are also presented since outflyer values influenced the averages significantly, especially in the case of insulin concentrations. The median blood glucose and serum insulin concentrations were therefore used to construct Fig. 1 and 2, representing the responses of the two groups graphically. The results of the statistical tests are also shown in the Table.

As could be expected, the kwashiorkor patients

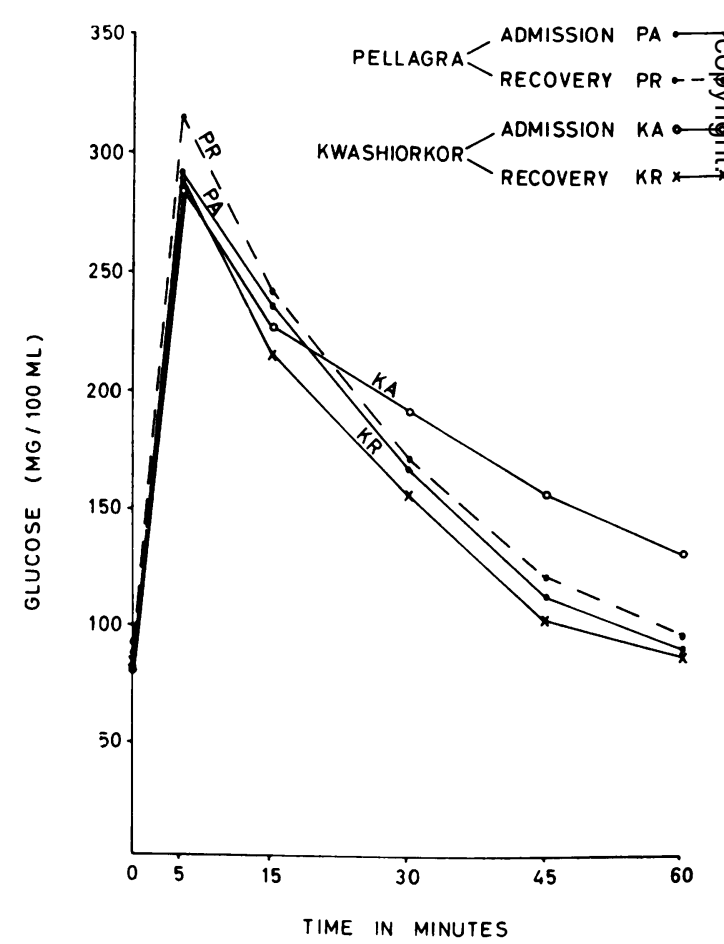

FIG. 1.-Intravenous glucose tolerance tests of kwashiorkor and pellagra groups, on admission and after recovery (median values). 


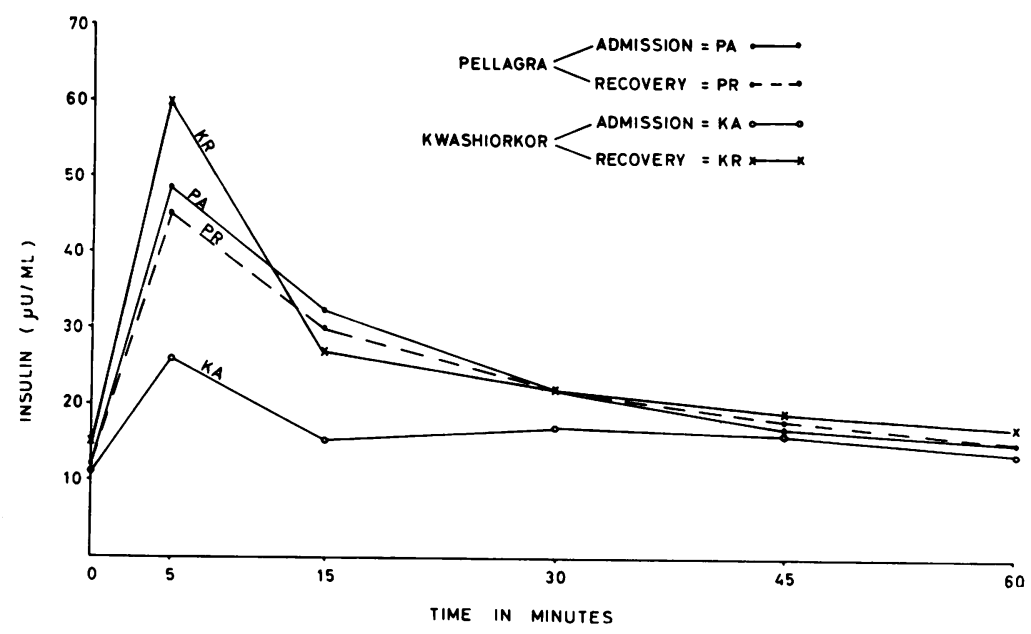

FIG. 2.-Insulin responses during intravenous tolerance tests of kwashiorkor and pellagra groups, on admission and after recovery (median values).

were on the average much younger $(11.4$ months) than their pellagra counterparts ( 84.5 months). The kwashiorkor group had a lower percentage expected weight (in spite of oedema), lower $\mathrm{Hb}$, and much lower serum albumin values on admission than the pellagra group, and the differences were significant $(P<0.05)$. Anaemia was not a prominent feature, but the pellagra group had higher $\mathrm{Hb}$ values than the kwashiorkor group, both on admission and after recovery and the differences were significant $(P<0.05)$ at both periods. Only in the kwashiorkor group did the $\mathrm{Hb}$ levels increase significantly from admission to recovery. The serum albumin concentrations of both groups increased significantly from admission to recovery, and in contrast to the position on admission, the levels of the two groups did not differ significantly on recovery.

On admission the kwashiorkor group's decline of blood glucose concentrations after glucose injection was slower between 15 and 60 minutes than that of the pellagra group; the differences were significant, however, at the 45- and 60-minute intervals only. The fasting blood sugar values of the two groups were similar at this stage. In accordance with the delayed decline of blood sugar levels, the initial median $\mathrm{K}$ value of the kwashiorkor group was 1.82 in comparison with 2.57 for the pellagra group, the difference being significant $(P<0.05)$. Though the $K$ values of the 2 groups did not differ significantly after recovery, the kwashiorkor group had significantly lower blood sugar values (including the fasting level) than the pellagra group at all stages except at the 30-minute interval of the tolerance test, in contrast to having had values higher than the pellagra patients at 30 , 45 , and 60 minutes on admission. In the case of the kwashiorkor group, the glucose assimilation rate ( $K$ value) was significantly better after recovery (median value $2 \cdot 58$ ) than initially (median value $1 \cdot 82$ ). This is also exemplified by the significantly lower blood sugar concentrations of the kwashiorkor group at 30, 45, and 60 minutes in comparison with their respective admission values. The pellagra patients' fasting blood sugar levels were significantly higher on recovery than initially, while their other glucose values were similar, including the glucose assimilation rate which was normal at both periods.

On admission the serum insulin response of the pellagra patients tended to be higher than that of the kwashiorkor group (see median values). At this stage the insulin values of the two groups differed significantly at 5,15 , and 30 minutes. The insulin levels of both groups showed no significant difference from admission to recovery, neither was any difference found between the two groups after recovery. The kwashiorkor group had, however, generally higher values after recovery than initially, and the response at 5 minutes just missed significance, mainly due to a lesser (but still normal) response of 2 of the patients. No correlation between serum insulin and albumin concentrations was found. 
Ages, Body Weights, Certain Blood Constituents, and Results of Statisticil T

\begin{tabular}{|c|c|c|c|c|}
\hline & $\begin{array}{c}\text { Age } \\
\text { (mth) }\end{array}$ & $\begin{array}{l}\text { Weight } \\
(\mathbf{k g})\end{array}$ & $\begin{array}{c}\text { \% Expected } \\
\text { Weight }\end{array}$ & $\begin{array}{c}\text { Albumin } \\
(\mathrm{g} / 100 \mathrm{ml})\end{array}$ \\
\hline $\begin{array}{l}\text { Admission } \\
\text { Kwashiorkor } \\
\text { Median value } \\
\text { Average value } \\
\text { SD } \\
\\
\text { Pellagra } \\
\text { Median value } \\
\text { Average value } \\
\text { SD } \\
\text { Difference }\end{array}$ & $\begin{array}{c}24 \cdot 0 \\
26 \cdot 7 \\
11 \cdot 41 \\
\\
72 \cdot 0 \\
84 \cdot 5 \\
29 \cdot 70 \\
S^{\star}\end{array}$ & $\begin{array}{c}8 \cdot 2 \\
8 \cdot 8 \\
1 \cdot 61 \\
\\
\\
18 \cdot 0 \\
18 \cdot 4 \\
4 \cdot 63 \\
S\end{array}$ & $\begin{array}{c}69 \cdot 75 \\
69 \cdot 2 \\
7 \cdot 78 \\
\\
80 \cdot 8 \\
80 \cdot 8 \\
15 \cdot 16 \\
S\end{array}$ & $\begin{array}{l}1 \cdot 85 \\
1.95 \\
0.404 \\
\\
3.06 \\
3 \cdot 15 \\
0.576 \\
S\end{array}$ \\
\hline $\begin{array}{l}\text { Recovery } \\
\text { Kwashiorkor } \\
\text { Median value } \\
\text { Average value } \\
\text { SD } \\
\\
\text { Pellagra } \\
\text { Median value } \\
\text { Average value } \\
\text { SD } \\
\text { Difference }\end{array}$ & & $\begin{array}{c}9 \cdot 90 \\
10 \cdot 36 \\
2 \cdot 257 \\
\\
18 \cdot 2 \\
20 \cdot 45 \\
5 \cdot 560 \\
S\end{array}$ & $\begin{array}{l}76 \cdot 5 \\
79 \cdot 3 \\
10 \cdot 62 \\
\\
82 \cdot 8 \\
88 \cdot 9 \\
14 \cdot 62 \\
S\end{array}$ & $\begin{array}{l}3 \cdot 86 \\
3 \cdot 76 \\
0 \cdot 635 \\
\\
3 \cdot 87 \\
3 \cdot 83 \\
0 \cdot 818 \\
\text { NS }\end{array}$ \\
\hline $\begin{array}{l}\text { Differences between admission and recovery values } \\
\text { Kwashiorkor } \\
\text { Pellagra }\end{array}$ & 二 & $\begin{array}{l}\mathbf{S} \\
\mathbf{S}\end{array}$ & $\begin{array}{l}\mathbf{S} \\
\mathbf{S}\end{array}$ & $\begin{array}{l}\mathbf{S} \\
\mathbf{S}\end{array}$ \\
\hline
\end{tabular}

\section{Discussion}

Kwashiorkor patients were unable to utilize glucose effectively during the acute stage, as exemplified by sustained high blood sugar levels and low K values. According to Loeb (1966) the blood sugar concentration after an intravenous tolerance test should reach an arbitrary value of $100 \mathrm{mg} / 100 \mathrm{ml}$ between 35 and 60 minutes. The glucose assimilation coefficient ( $K$ value) normally varies between 1.7 and 3.9 , and after the first days of life remains constant throughout childhood up to puberty (Loeb, 1966). The initial mean K value of 1.61 for the kwashiorkor group in the present study is very near to the value of 1.55 reported by Bowie (1964) from Cape Town. The ability of the kwashiorkor group to dispose of glucose improved after recovery, as exemplified by the rise in $K$ values and the significant lower mean blood sugar levels of $146 \cdot 4,100 \cdot 4$, and $87 \cdot 4$ $\mathrm{mg} / 100 \mathrm{ml}$ at 30,45 , and 60 minutes, respectively, in comparison with $177 \cdot 1,143 \cdot 6$, and $129.5 \mathrm{mg} /$ $100 \mathrm{ml}$ at comparable intervals on admission. In fact, after recovery the kwashiorkor group had significantly lower blood sugar levels than the pellagra patients at all stages except 30 minutes. Furthermore, the insulin concentrations of the two groups did not differ appreciably at any stage after recovery, whereas the kwashiorkor group had significantly lower levels at 5,15 , and 30 minutes initially. However, though the median insulin concentrations of the kwashiorkor patients were higher after recovery than on admission, especially at 5 and $\mathbf{1 5}$ minutes, the improvement in glucose tolerance could not be definitely related to insulin secretion, since their insulin values did not differ significantly from admission to recovery. In contrast the pellagra patients generally had, both on admission as well as after recovery, normal and similar glucose tolerance tests, $K$ values, and insulin responses. No suitable explanation can be offered for their higher fasting blood sugar levels after recovery in comparison with their initial levels. It is probable that in kwashiorkor severe depletion of body potassium (Garrow, Smith, and Ward, 1968) is an important contributory cause towards impaired glucose disposal. Potassium deficiency is known to diminish glucose utilization (Gardner et al., 1950; Kinsell, Balch, and Michaels, 1953). Furthermore, patients with primary hyperaldosteronism and potassium deficiency had impaired carbohydrate tolerances which returned to normal after removal of the adrenal tumours (Conn, 1964).

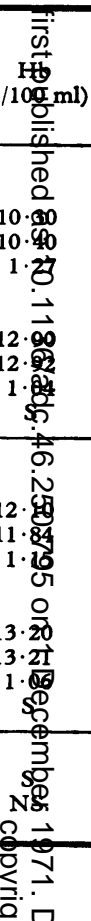

要

(O) $\mathrm{ml}$ 
n Admission and After Recovery, of Patients with Kwashiorkor and Pellagra

\begin{tabular}{|c|c|c|c|c|c|c|c|c|c|c|c|c|}
\hline \multicolumn{6}{|c|}{$\begin{array}{l}\text { Intravenous Blood Glucose Tolerance Results } \\
(\mathrm{mg} / 100 \mathrm{ml} \text { at different times in minutes) }\end{array}$} & \multicolumn{6}{|c|}{$\begin{array}{l}\text { Serum Insulin Concentrations } \\
(\mu \mathrm{U} / \mathrm{ml} \text { at different times in minutes })\end{array}$} & \multirow{2}{*}{$\begin{array}{r}\mathbf{K} \\
\text { Value }\end{array}$} \\
\hline 0 & 5 & 15 & 30 & 45 & 60 & 0 & 5 & 15 & 30 & 45 & 60 & \\
\hline $\begin{array}{l}80 \cdot 0 \\
85 \cdot 1 \\
20 \cdot 26\end{array}$ & $\begin{array}{c}286 \cdot 0 \\
287 \cdot 3 \\
54 \cdot 58\end{array}$ & $\begin{array}{c}227 \cdot 0 \\
233 \cdot 3 \\
42 \cdot 56\end{array}$ & $\begin{array}{c}191 \cdot 5 \\
177 \cdot 1 \\
33 \cdot 55\end{array}$ & $\begin{array}{c}156 \cdot 0 \\
143 \cdot 6 \\
35 \cdot 17\end{array}$ & $\begin{array}{c}130 \cdot 5 \\
129 \cdot 5 \\
47.95\end{array}$ & $\begin{array}{l}11 \cdot 5 \\
15 \cdot 9 \\
18 \cdot 26\end{array}$ & $\begin{array}{l}26 \cdot 0 \\
85 \cdot 7 \\
176 \cdot 28\end{array}$ & $\begin{array}{c}15 \cdot 5 \\
56 \cdot 7 \\
130 \cdot 35\end{array}$ & $\begin{array}{c}17 \cdot 0 \\
45 \cdot 4 \\
110 \cdot 83\end{array}$ & $\begin{array}{l}16 \cdot 0 \\
37 \cdot 3 \\
87 \cdot 09\end{array}$ & $\begin{array}{l}13 \cdot 5 \\
21 \cdot 2 \\
28 \cdot 86\end{array}$ & $\begin{array}{l}1 \cdot 82 \\
1 \cdot 61 \\
0 \cdot 881\end{array}$ \\
\hline $\begin{array}{l}88 \cdot 0 \\
85 \cdot 1 \\
11 \cdot 12 \\
\text { NSt }\end{array}$ & $\begin{array}{c}291 \cdot 0 \\
291 \cdot 6 \\
44 \cdot 36 \\
\text { NS }\end{array}$ & $\begin{array}{c}236 \cdot 0 \\
229 \cdot 9 \\
37 \cdot 53 \\
\text { NS }\end{array}$ & $\begin{array}{c}166 \cdot 5 \\
159 \cdot 9 \\
44 \cdot 46 \\
\text { NS }\end{array}$ & $\begin{array}{c}113 \cdot 0 \\
112 \cdot 9 \\
25 \cdot 85 \\
S\end{array}$ & $\begin{array}{c}90 \cdot 0 \\
93 \cdot 2 \\
16 \cdot 27 \\
S\end{array}$ & $\begin{array}{c}12 \cdot 0 \\
12 \cdot 9 \\
5 \cdot 06 \\
\text { NS }\end{array}$ & $\begin{array}{c}48 \cdot 5 \\
96 \cdot 0 \\
134 \cdot 68 \\
\quad S\end{array}$ & $\begin{array}{c}32 \cdot 5 \\
61 \cdot 4 \\
62 \cdot 77 \\
\quad \mathrm{~S}\end{array}$ & $\begin{array}{c}22 \cdot 0 \\
27 \cdot 5 \\
10 \cdot 2 \\
\mathrm{~S}\end{array}$ & $\begin{array}{c}17 \cdot 0 \\
18 \cdot 9 \\
5 \cdot 90 \\
\text { NS }\end{array}$ & $\begin{array}{c}15 \cdot 0 \\
15 \cdot 5 \\
4 \cdot 26 \\
\text { NS }\end{array}$ & $\begin{array}{c}2 \cdot 57 \\
2 \cdot 55 \\
0 \cdot 770 \\
\mathrm{~S}\end{array}$ \\
\hline $\begin{array}{l}84 \cdot 0 \\
79 \cdot 6 \\
12 \cdot 72\end{array}$ & $\begin{array}{c}285 \cdot 0 \\
283 \cdot 6 \\
22 \cdot 42\end{array}$ & $\begin{array}{c}215 \cdot 5 \\
218 \cdot 1 \\
23 \cdot 96\end{array}$ & $\begin{array}{c}155 \cdot 5 \\
146 \cdot 4 \\
28 \cdot 27\end{array}$ & $\begin{array}{c}102 \cdot 0 \\
100 \cdot 4 \\
19 \cdot 83\end{array}$ & $\begin{array}{l}87 \cdot 0 \\
87 \cdot 4 \\
13 \cdot 70\end{array}$ & $\begin{array}{l}15 \cdot 0 \\
17 \cdot 9 \\
13 \cdot 89\end{array}$ & $\begin{array}{c}60 \cdot 0 \\
100 \cdot 2 \\
148 \cdot 82\end{array}$ & $\begin{array}{c}27 \cdot 0 \\
64 \cdot 7 \\
143 \cdot 06\end{array}$ & $\begin{array}{l}22 \cdot 0 \\
27 \cdot 8 \\
19 \cdot 25\end{array}$ & $\begin{array}{l}19 \cdot 0 \\
20 \cdot 8 \\
12 \cdot 53\end{array}$ & $\begin{array}{l}17 \cdot 0 \\
18 \cdot 1 \\
11 \cdot 68\end{array}$ & $\begin{array}{l}2 \cdot 58 \\
2 \cdot 68 \\
0 \cdot 532\end{array}$ \\
\hline $\begin{array}{l}\text { NS } \\
\text { S }\end{array}$ & $\begin{array}{l}\text { NS } \\
\text { NS }\end{array}$ & $\begin{array}{l}\text { NS } \\
\text { NS }\end{array}$ & $\begin{array}{c}\text { S } \\
\text { NS }\end{array}$ & $\begin{array}{c}\text { S } \\
\text { NS }\end{array}$ & $\begin{array}{c}\text { S } \\
\text { NS }\end{array}$ & $\begin{array}{l}\text { NS } \\
\text { NS }\end{array}$ & $\begin{array}{l}\text { NS } \\
\text { NS }\end{array}$ & $\begin{array}{l}\text { NS } \\
\text { NS }\end{array}$ & $\begin{array}{l}\text { NS } \\
\text { NS }\end{array}$ & $\begin{array}{l}\text { NS } \\
\text { NS }\end{array}$ & $\begin{array}{l}\text { NS } \\
\text { NS }\end{array}$ & $\begin{array}{c}\text { S } \\
\text { NS }\end{array}$ \\
\hline
\end{tabular}

In marasmus there is a normal proportion of potassium to body weight (Garrow, et al., 1968) and a normal carbohydrate tolerance (Bowie, 1964). Pellagra subjects, being non-oedematous and less acutely ill than kwashiorkor patients, are presumably not potassium deficient and, like marasmic children, have normal glucose tolerances.

Our results concerning the kwashiorkor patients, namely a return towards normality of glucose assimilation and insulin response after recovery, seem to be contradictory to the reports of James and Coore (1970), and Cook (1968). Cook's patients who had had kwashiorkor do not, however, seem to have been in good health at the time of study since $45 \%$ had parotid enlargement, $26 \%$ had splenomegaly, and $19 \%$ had hepatomegaly. James and Coore (1970) in fact showed that patients who had recovered from protein-calorie-malnutrition had an improved average insulin response, though it was less than that of a group of 5 normal children. The insulin data were apparently not subjected to statistical analyses. Furthermore, there is a wide range of insulin values at any one sampling time and the data do not have a normal distribution. Welborn et al. (1966) thus suggested that log insulin values, which are normally distributed, be used. Since the median values are not influenced by extremes and are unrelated to the skewness of the curve, they were tabulated in addition to the average values in the Table, and were used for the construction of Fig. 2. It is probable that graphs and tables based on average insulin values are not fully representative of the true state of affairs. However, the improvement in glucose utilization which took place on recovery of the kwashiorkor group, as well as the low incidence of diabetes mellitus in the Bantu (Walker, 1966), cast doubt on the concept of permanent impairment of pancreatic endocrine function as a result of proteincalorie-malnutrition.

We thank the Medical Superintendent of the $H$. F. Verwoerd Hospital, and Professor P. J. Pretorius, head of the Department of Paediatrics, for clinical facilities and permission to publish, Professor L. S. de Villiers of the Institute for Pathology, University of Pretoria, for the serum protein and blood sugar estimations, and Dr. N. F. Laubscher of the National Research Institute for Mathematical Sciences for statistical advice.

\section{REFBRENCES}

Baig, H. A., and Edozien, J. C. (1965). Carbohydrate metabolism in kwashiorkor. Lancet, $2,662$.

Barbezat, G. O., and Hansen, J. D. L. (1968). The exocrine pancreas and protein-calorie-malnutrition. Pediatrics, 42, 77. 
Bowie, M. D. (1964). Intravenous glucose tolerance in kwashiorkor and marasmus. South African Medical fournal, 38, 328.

Carter, J. P., Kattab, A., Abd-El-Hadi, K., Davis, J. T., El Gholmy, A., and Patwardhan, V. N. (1968). Chromium (III) in hypoglycemia and in impaired glucose utilization in kwashiorkor. American fournal of Clinical Nutrition, 21, 195.

Conn, J. W. (1964). Hypertension, the potassium ion and impaired carbohydrate tolerance. New England fournal of Medicine, 273, 1135.

Cook, G. C. (1968). Glucose and starch tolerance after recovery from kwashiorkor. Metabolism: Clinical and Experimental, $17,1073$.

Gardner, L. I., Talbot, N. B., Cook, C. D., Berman, H., and Uribe, C. (1950). The effect of potassium deficiency on carbohydrate metabolism. Fournal of Laboratory and Clinical Medicine, 35, 592.

Garrow, J. S., Smith, R., and Ward, E. E. (1968). Electrolyte Metabolism in Severe Infantile Malnutrition, chapter 6, p. 75. Pergamon Press, London.

Gillman, J., and Gillman, T. (1951). Perspectives in Human Malnutrition, p. 283. Grune and Stratton, New York.

Hadden, D. R. (1967). Glucose, free fatty acid, and insulin interrelations in kwashiorkor and marasmus. Lancet, 2, 589.

Hales, C. N., and Randle, P. J. (1963). Immunoassay of insulin with insulin-antibody precipitate. Biochemical fournal, 88, 137.

Hoffman, W. S. (1937). A rapid photoelectric method for the determination of glucose in blood and urine. fournal of Biological Chemistry, 120, 51.

Hopkins, L. L., Jr., Ransome-Kuti, O., and Majaj, A. S. (1968). Improvement of impaired carbohydrate metabolism by chromium (III) in malnourished infants. American fournal of Clinical Nutrition, 21, 203.

James, W. P. T., and Coore, H. G. (1970). Persistent impairment of insulin secretion and glucose tolerance after malnutrition. American fournal of Clinical Nutrition, 23, 386.
Kinsell, L. W., Balch, H. E., and Michaels, G. D. (1953). Modification of 'steroid diabetes' by potassium. Metabolism: Clinical and Experimental, 2, 421.

Loeb, H. (1966). Variations in glucose tolerance during infancy and childhood. Fournal of Pediatrics, 68, 237.

Lundbaek, $K$. (1962). Intravenous glucose tolerance as a tool in definition and diagnosis of diabetes mellitus. British Medical fournal, 1, 1507.

Nelson, W. E. (1964). Textbook of Pediatrics, 8th ed., p. 48 Saunders, Philadelphia and London.

Prinsloo, J. G., de Bruin, E. J. P., Laubscher, N. F., Venter, L. M., and Kruger, H. (1971). Comparison of oral glucose-tolerance tests and serum insulin responses in pellagra and kwashiorkor. South African Medical fournal, 45, 554.

Siegel, S. (1956). Non-Parametric Statistics for the Behavioral Sciences, p. 116. McGraw-Hill, New York.

Walker, A. R. P. (1966). Nutritional, biochemical, and other studies on South African populations. Studies on glycosuria, glucose tolerance and diabetes in South African populations. South African Medical fournal, 40, 841.

Weichselbaum, T. E. (1946). An accurate and rapid method for the determination of proteins in small amounts of blood serum and plasma. American fournal of Clinical Pathology, 16, Tech. Sect., 10, 40.

Welborn, T. A., Rubenstein, A. H., Haslam, R., and Fraser, R. (1966). Normal insulin response to glucose. Lancet, 1, 280

Wharton, B. (1970). Hypoglycaemia in children with kwashiorkor. Lancet, 1, 171.

Correspondence to Dr. J. G. Prinsloo, Department of Paediatrics, Faculty of Medicine, P.O. Box 667, Pretoria, South Africa. 